OPEN ACCESS

Edited by:

Biruh Workeneh,

University of Texas MD Anderson

Cancer Center, United States

Reviewed by:

Florian Grahammer,

Universitätsklinikum

Hamburg-Eppendorf, Germany

Gaurav Gupta,

Virginia Commonwealth University,

United States

*Correspondence:

Joy V. Nolte Fong

jvnoltefong@houstonmethodist.org

Specialty section:

This article was submitted to

Nephrology

a section of the journa

Frontiers in Medicine

Received: 07 May 2018 Accepted: 11 October 2018

Published: 31 October 2018

Citation:

Nolte Fong JV and Moore LW (2018) Nutrition Trends in Kidney Transplant

Recipients: the Importance of Dietary

Monitoring and Need for

Evidence-Based Recommendations.

Front. Med. 5:302

doi: 10.3389/fmed.2018.00302

\section{Nutrition Trends in Kidney Transplant Recipients: the Importance of Dietary Monitoring and Need for Evidence-Based Recommendations}

\author{
Joy V. Nolte Fong* and Linda W. Moore \\ Department of Surgery, Houston Methodist Hospital, Houston, TX. United States
}

Many physiological properties of the renal system influence nutrient metabolism, elimination, and homeostasis. Kidney failure poses significant challenges to maintaining adequate nutrition, most of which transplantation ameliorates. Comprehensive recommendations for managing nutritional derangements for patients with chronic kidney disease and end stage renal disease exist; however, there are only sparse guidelines for post-transplant malnutrition and adverse outcomes. Not only are guidelines limited, but little is known about dietary trends of post-kidney transplant recipients. This review describes guidelines for prevalent metabolic and nutritional complications post-kidney transplantation and also evaluates changes in caloric intake and diet composition after transplantation. This topic is important because nutrition influences allograft function and a number of cardiovascular risk factors including blood pressure, dyslipidemia, weight, and diabetes. In addition, many dietary recommendations and modifiable lifestyle changes should be tailored for specific complications of transplant patients, namely immunosuppression side effects, dietary restrictions, and electrolyte imbalances.

Keywords: renal transplantation, transplant comorbidities, nutrition interventions, dietary patterns, renal diet

\section{INTRODUCTION}

Many physiological properties of the renal system influence nutrient metabolism, elimination, and electrolyte homeostasis. Kidney failure poses a significant challenge to maintaining adequate nutrition and muscle mass. Protein-calorie malnutrition and muscle mass loss, which has been linked to increased mortality after transplant $(1,2)$, is prevalent in up to a fifth of kidney transplant recipients at time of transplant (3). Thus, establishing a healthy diet and metabolic profile to correct pre-transplant malnutrition and prevent progression or development of malnutrition post-transplant is of vital importance.

Prevention of several adverse post-transplant outcomes such as cardiovascular disease, dyslipidemia, new onset diabetes after transplantation (NODAT), and even bone loss can be achieved through diet and exercise. Although numerous studies report weight gain after kidney transplantation (KT) (4-7) there are limited guidelines addressing diet or physical activity for this population to deter this unwanted gain.

Transitioning from end stage renal disease to transplantation poses a metabolic challenge due to hormonal shifts, energy expenditure variance, and the metabolic derangements associated with immunosuppression therapies. Additionally, food restrictions vary pre- and post-transplant, from 
avoiding phosphorus-rich dairy and high-potassium foods on dialysis to avoiding food-borne pathogens post-transplant [although there is limited evidence to support this particular common diet recommendation (8)]. These, along with other lifestyle changes, influence the health behaviors of kidney transplant recipients.

The purpose of the article is to review current nutritional guidelines for post-kidney transplant patients and highlight nutrition trends and results from dietary interventions. Pre-transplant malnutrition along with a full review of micronutrients and electrolytes are not the scope of this paper, however, should not go without consideration.

\section{METHODS}

PubMed, Scopus, and the Cochrane Database of Systematic Reviews were searched for the articles included in this review. These articles were also reference-mined for determining other relevant references. Articles focusing on micronutrient contribution to nutrition pre-KT were excluded. Due to the volume of micronutrient and electrolyte derangements, the top three most frequently studied micronutrients were included.

\section{PRACTICE GUIDELINES}

There are seven major authorities with similar approaches for creating renal clinical practice guidelines worldwide (9). The Kidney Disease Improving Global Outcomes (KDIGO) workgroup developed clinical practice guidelines based on a methodic evidence-based analysis process specifically focused on prevention of post-transplant complications (10). The KDIGO guidelines do not offer insights specifically on dietary recommendations for kidney transplant recipients. Rather, the guidelines focus more on the management of metabolic derangements: diabetes mellitus and NODAT; hypertension, dyslipidemia, and obesity; cardiovascular disease; and transplant bone disease.

Furthermore, a systematic review in 2009 revealed that of 119 relevant articles, there was no scientific evidence of a grade I or II that exists for dietary recommendations for kidney transplant recipients (11). Although guidelines exist for common comorbidities of KT for the general population, specific considerations in $\mathrm{KT}$ must be incorporated into developing quality guidelines to prevent or control metabolic disorders posttransplant.

\section{MACRONUTRIENTS}

Macronutrients comprise a pivotal aspect of nutrition guidelines. Here we briefly explore each macronutrient with post-transplant complications and comorbidity prevention in mind.

\section{Fat}

Lipids present a large portion of the American diet (12), and it is recommended for adults to consume between 20 and $35 \%$ of calories from fat while maintaining $10 \%$ or less from saturated fatty acids (13). Comorbidities associated with elevated fat intake include dyslipidemia, hyperglycemia, cardiovascular disease, and high blood pressure-all elevated risk factors after kidney transplantation-enhance the likelihood of developing cardiovascular disease (CVD) (14).

Mechanisms of energy storage and utilization link free fatty acids (FFAs) to insulin resistance (IR) through various cell signaling pathways that are regulated by insulin (15). Weight gain, particularly visceral fat gain, elevates FFA concentration and enhances insulin resistance via inhibiting insulin receptors on the cellular membrane (16).

In a cohort of $85 \mathrm{KTR}$, insulin resistance [measured by the homeostasis model assessment (HOMA-IR)] had no significant association with FFA $(p=0.09)$ nor controls $(p=0.24)$. However, when controlling for sex, an association between FFA and IR was found in males $(p=0.002)$ but not females $(p=0.04)$. Regarding atherosclerotic events, FFA have shown contrasting impact on renal epithelium in vivo (17). Albumin, filtered through the proximal tubule during proteinuria, serves as a carrier protein for FFA, and these protein-bound fatty acids may contribute renal damage caused by proteinuria (18). Klooster et al. demonstrated that non-esterified fatty acids bound to albumin showed a reduced risk of graft failure $(\mathrm{HR}=0.61$, $p<0.001)$ in a model controlling for gender in KTR $(n=461)$ (19). Mechanisms for this effect have not been elucidated, nor has the exogenous fatty acid profile been scrutinized to optimize the renoprotective benefits. This study also found no difference in diabetic parameters, i.e., HgbA1c and insulin resistance, among tertiles of non-esterified fatty acids concentrations.

Furthermore, studies showing the protective effect on renal epithelium associated with monounsaturated fatty acids $(20,21)$ and polyunsaturated fatty acids [eicosapentaenoic acid (EPA), docosahexaenoic acid (DHA) and alpha-linolenic acid (ALA)], have mixed outcomes within the KTR population (22). A posthoc analysis of $673 \mathrm{KTR}$ with food frequency questionnaires demonstrated a relationship between omega- 3 fatty acids and graft and patient outcomes (23). When divided into tertiles based on dietary ALA intake, the highest tertile was associated with twice the risk of mortality compared to the lowest tertile (HR 2.21; 95\% CI 1.23, 3.97). The authors suggested glucocorticoid steroids may contribute to this by altering the ALA:EPA-DHA ratio through inhibition of the $\Delta 5$ and $\Delta 6$ desaturates (24)-the rate limiting step in converting ALA into EPA and DHA $(24,25)$. No omega-3 fatty acids were associated with graft loss.

A Cochrane database review demonstrated that there is not enough evidence to recommend the use of omega- 3 fatty acid supplementation due to only modest improvements in high density lipoprotein and diastolic blood pressure (22). The main concern regarding this topic in transplantation is a lack of welldesigned, prospective, placebo-controlled studies of omega-3 fatty acid supplementation (or a dietary regimen).

Dietary lipids can have a direct impact on the health and function of renal tissues, but stored body fat, in particular as a result of post-transplant weight gain, plays a role in disease development as well. Although the prevalence of sarcopenia and malnutrition are high pre-KT (2), clinicians must be cognizant of the type of weight gained and where the weight is deposited. 


\section{Protein}

Dietary recommendations for protein intake have been studied extensively in patients with CKD (26) but very few guidelines exist for kidney transplant recipients. Increased protein intake is associated with elevated blood pressure, secondary graft failure, and cardiovascular events.

Important considerations post-transplant include preventing muscle loss after surgery and achieving positive nitrogen balance. Associated short-term factors include wound healing and the added stress of surgical insult to the body. The early increased need for protein utilization should be accompanied by adequate dietary intake to limit a negative protein balance. Protein recommendations immediately post-operatively range from 1.3 to $2 \mathrm{~g} / \mathrm{kg}$ of body weight (27).

A review concluded that there is no definitive guideline regarding protein recommendations peri-operatively for kidney transplant patients (28). With a lack of long-term evidence for protein needs post-transplant, an acceptable range to consume for allograft and overall physiological maintenance is $0.75 \mathrm{~g} / \mathrm{kg} / \mathrm{d}$ for females and $0.8 \mathrm{~g} / \mathrm{kg} / \mathrm{d}$ for males (28).

\section{Carbohydrate}

Despite increased awareness of NODAT and complications early post-transplant, there is no consensus on treatment or therapies (29). Carbohydrates ( $\mathrm{CHO})$ contribute the highest amount of energy in the typical American diet, making up 50\% of total kilocalories from a recent report from 2007 to 2012 NHANES data (12). The Dietary Guidelines for Americans recommend a diet with carbohydrate intake of $45-65 \%$ of total kilocalories (13). Hyperglycemia and type 2 diabetes mellitus (T2DM) in nontransplant patients who followed a low glycemic diet were found to have reduced risk of micro- and macro-vascular complications (30).

Persistent excess $\mathrm{CHO}$ intake that is broken down into glucose causes an increased risk for developing dyslipidemia, metabolic syndrome and NODAT. In a recent retrospective analysis of 407 patients, age $(p=0.018)$, high density lipoprotein (HDL) $(p=0.010)$, and average tacrolimus trough level $(p<0.0001)$ were risk factors for hyperglycemia post-transplant (31). Similarly, predictors of recurrent hyperglycemia included age $(\mathrm{p}<0.0001)$, HDL $(p=0.003)$, non-White race $(p=0.002)$, and using steroids $(p=0.007)$. Conversely, a larger retrospective study found that incidence of NODAT depended on the immunosuppression regimen and that steroid-free regimens reduced the odds of developing diabetes after transplantation by $42 \%$ after 3 years (32). To date, the only prospective, double-blind, randomized, placebo-controlled study of the use of corticosteroids vs. placebo in kidney transplant recipients determined that early (day 7 post-transplant) withdrawal of corticosteroids had little impact on the development of NODAT over the 5-year follow-up period (33). This study further demonstrated no difference in weight gained between the corticosteroid withdrawal group and the group maintained on corticosteroids during the 5-year study (34), strongly suggesting that the development of NODAT and the post-transplant weight gain is not due to the use of corticosteroids in the current era. This study did not evaluate dietary intake of the participants.
Considerations peri-transplant involve high dose corticosteroid use and wound healing (35). Furthermore, the innate stress response from the surgery initiates a cascade of hyperglycemia. Elevated serum glucose increases the risk of blood stream infections (36) and hampers wound healing (37) Furthermore, hyperglycemia increases reactive oxygen species that may exhaust antioxidants pools (38).

\section{KEY MICRONUTRIENTS}

There are several electrolytes and micronutrients that use the renal system for excretion and reabsorption, most of which are altered by immunosuppression therapies and residual derangements prior to transplant. Considerable research on three main micronutrients emerged in KTR: phosphorous, magnesium, and vitamin D. Trends in their relationship to transplantation are listed below and relevant nutrient information is listed in Table $\mathbf{1 .}$

\section{Phosphorus}

Post-transplant patients tend to revert to hypophosphatemia immediately post-transplant (39) due to several factors including hyperabsorption from bones, secondary parathyroidism, and fibroblast growth factor 23 normalization (40). In a study analyzing over 28,000 phosphate measurements for $957 \mathrm{KTR}$, researchers observed the lowest median serum phosphate level around 1 month post-KT (41). They also found an association between low phosphate levels and a reduced risk in graft failure and cardiovascular disease (CVD) mortality, but not all-cause mortality.

Data from the Folic Acid for Vascular Outcome Reduction in Transplantation (FAVORIT) trial (42) also investigated longterm KTR phosphorus status and found an increased in transplant failure and total mortality but not CVD (HR: 1.36, 95\% CI 1.15-1.62, HR: 1.21, 95\% CI 1.04-1.4, and HR 1.06, 95\% CI 0.92-1.22, respectively). Two recent studies showed elevated serum phosphorus was associated with KTR mortality and graft loss $(43,44)$. Conversely, there are studies that do not find correlations or increased risk with serum phosphorus and graft outcomes (45).

\section{Magnesium}

Magnesium ( $\mathrm{Mg}$ ) deficiency is common but often undiagnosed in KTR due to physiological regulation. The surge of calcineurin inhibitors (CNI) use increases magnesium wasting through down regulating the Transient Receptor Potential Melastatin 6 (TRPM6) in the distal collecting tubule $(46,47)$. In large cohort (48) and meta-analysis studies (49-52), hypomagnesaemia and poor $\mathrm{Mg}$ dietary intake are associated with T2DM in non-KTR. This is observation has been explored through randomized controlled trials (RCTs), yet outcomes do not fully support the hypothesis the supplementation impacts glucose homeostasis.

Some supplementation studies have been poorly tolerated, underpowered, or showed minimal increase in $\mathrm{Mg}$ serum status. A recent study supplemented hypomagnesaemic KTRs within 2 weeks of transplantation for 3 months and compared glucose 
TABLE 1 | Key nutrients to consider for post-transplant kidney recipients based on recommendations for healthy adults.

\begin{tabular}{|c|c|c|c|}
\hline Nutrient & Key functions & RDA per day (Dietary Guidelines, 2015) & Common food sources \\
\hline $\begin{array}{l}\text { Dietary fats, gm-can consist of } \\
\text { DHA/EPA, polyunsaturated fatty } \\
\text { acids, monounsaturated fatty acids, } \\
\text { and saturated fatty acids }\end{array}$ & $\begin{array}{l}\text { - Thermal regulation } \\
\text { - Cell membranes } \\
\text { - Fat-soluble vitamin digestion } \\
\text { - Energy } \\
\text { - Satiety }\end{array}$ & $\begin{array}{l}20-30 \% \text { of total energy with }<10 \% \text { from } \\
\text { saturated fats }\end{array}$ & $\begin{array}{l}\text { Fatty fish (salmon, tuna, mackerel) } \\
\text { Avocados } \\
\text { Animal meats } \\
\text { Nuts } \\
\text { Dairy } \\
\text { Oils }\end{array}$ \\
\hline Phosphorus, mg & $\begin{array}{l}\text { - Bones and teeth } \\
\text { - Energy (ATP) } \\
\text { - Enzyme cofactor } \\
\text { - Backbone of DNA/RNA }\end{array}$ & 1,250 & $\begin{array}{l}\text { Chicken/turkey } \\
\text { Pork } \\
\text { Organ meats } \\
\text { Dairy } \\
\text { Dark sodas } \\
\text { Preserved fish } \\
\text { Nuts } \\
\text { Whole grains }\end{array}$ \\
\hline Magnesium, mg & $\begin{array}{l}\text { - T cell regulation } \\
\text { - ATPase activity } \\
\text { - 300+ coenzyme activities } \\
\text { - Cardiovascular } \\
\text { - Regulates blood glucose } \\
\text { - Bone matrix } \\
\text { - Energy production } \\
\text { - Cell signaling }\end{array}$ & $\begin{array}{l}360 \text { for females } \\
410 \text { for males }\end{array}$ & $\begin{array}{l}\text { Cereals, bran } \\
\text { Nuts } \\
\text { Avocados } \\
\text { Dark chocolate } \\
\text { Brown rice } \\
\text { Spinach } \\
\text { Mackerel } \\
\text { Swiss chard }\end{array}$ \\
\hline
\end{tabular}

ATP, Adenosine triphosphate; DHA, docosahexaenoic acid; DNA, deoxyribose nucleic acid; EPA, eicosapentaenoic acid; RDA, Recommend Dietary Allowances.

homeostasis to a control group (53). This study showed an $11.5 \mathrm{mg} / \mathrm{dL}$ improvement in fasting glucose but no difference in insulin sensitivity. $\mathrm{Mg}$ supplementation (450 mg magnesium oxide, three times daily for 6 months) on hypomagnesaemic KTRs often does not demonstrate any change in insulin secretion (54-56).

\section{Vitamin D}

Inadequate or deficient vitamin $\mathrm{D}$ status is common in KTR compared to non-transplant controls (57) irrespective of sun exposure seasons (58). Vitamin D has been linked to several post-transplant comorbidities including polyoma virsus, acute rejection, and diabetes, yet there is evidence of providing a reno-protective effect as well (59).

\section{DISCUSSION}

The lack of dietary intake is a limitation among the majority of research studies investigating nutrient roles in kidney transplantation. In 1990, a group of 66 renal dietitians were surveyed to indicate nutrition recommendations for patients up to 21-days post-transplant (60). Dietary recommendations focused on normalizing nitrogen balance and minimizing diabetes and hyperlipidemia. Suggested macronutrient profiles 
included protein at $1.2-1.5 \mathrm{~g} / \mathrm{kg}$ body weight, carbohydrates $40-50 \%$ of total energy, and fat $<30 \%$ of total energy.

\section{Current Dietary Trends}

Few studies investigate dietary intakes and trends of KTR, especially longitudinally. The onset of NODAT within the first 6 months post-KT often occurs (61), therefore, early monitoring and intervention of dietary behavior could be very beneficial in combating post-KT comorbidities. In a cohort of $31 \mathrm{KTR}$, dietary recalls pre-KT and at 3 and 12 months post-transplant revealed different intakes at each time point, with the highest total energy, total fat, and saturated fat consumption at 3 months (62). Mean dietary fat increased $26 \mathrm{~g} / \mathrm{d}(p=0.01)$ and $18.3 \mathrm{~g} / \mathrm{d}$ $(p=0.02)$ at 3 and 12 months compared to pre-KT. On the other hand, a prospective analysis of dietary intake by $24 \mathrm{~h}$ recalls of $44 \mathrm{KTR}$, showed no significant difference in intake between time of transplant and 3 and 6 months post-KT (63). Mean total fat provided $\sim 37 \%$ of energy intake, CHO $44 \%$, and protein $18 \%$.

In a study investigating dietary patterns with a mean transplant duration of 5.6 years $(n=637)$, macronutrient profiles were $36 \%$ fat, $15 \%$ protein, and $45.8 \%$ carbohydrates (23), which are similar to the Dietary Guidelines discussed in previous sections.

In a dietary analysis of 632 Dutch KTR, the Dietary Approach to Stop Hypertension (DASH) score was calculated through food frequency questionnaires administered over 5 years (64). The highest tertile of DASH scores had more than a $50 \%$ reduction in both renal function decline $(\mathrm{HR}=0.57 ; 95 \% \mathrm{CI}, 0.33-0.96$, $P=0.03)$ and all-cause mortality $(\mathrm{HR}=0.52 ; 95 \% \mathrm{CI}, 0.32-0.83$, $P=0.006)$ when compared to the lowest group after controlling for age, kidney function, transplant characteristics, and sex.

In another trial comprised of two groups, Group 1 had insulin resistance or NODAT $(n=36)$ and received active lifestyle counseling, and Group 2 had normal glucose tolerance $(n=79)$ and only received leaflets on health behavior (65). Group 1 experienced a reduction in NODAT ( $n=7$ vs. $n=3$ ) while Group 2 experienced an increase in the number of participants who were glucose intolerant $(n=12)$. This study demonstrated that active lifestyle modification reversed insulin resistance compared to a passive approach.

\section{Dietary Intervention Studies in Kidney Transplantation}

Protocols that are underway or planned reveal strategies to investigate dietary and lifestyle interventions in KTR.
A randomized controlled trial in Brittan is investigating the difference of active vs. passive lifestyle intervention on cardiometabolic outcomes of KTR (66). Similarly, the INTENT trial (67) randomizes patients at least 1 -month post-KT to either standard of care or frequent visits of motivational interviewing techniques with a dietitian and exercise physiologist for 12 months. The Active Care after Transplantation trial (68) plans to enroll 216 KTR and randomize participants into one of three groups: standard of care, exercise only intervention, and diet plus exercise therapies for over 15 months.

Prior to these studies, very few RCT on dietary intervention have been conducted (69) and non-randomized trials showed mixed degrees of weight loss and impact on outcomes $(65,70,71)$.

\section{Dietary Recommendations}

Dietary recommendations are scarce for the post-KT community with most major international regulatory and advisory committees excluding this important aspect in clinical care guidelines. Dietary recommendations should be given with the intent to reduce comorbidities and micronutrient deficiencies. With few RCTs, it proves difficult to provide recommendations other than a targeted, individualistic approach. Many established diets including the DASH diet and Mediterranean diets are suitable for KTR, however, no longitudinal studies have been conducted in this population to date. Many factors in addition to lifestyle change and food preferences must be considered, namely immunosuppression regimens and postoperative course (i.e., recurrent infections or poor wound healing).

\section{CONCLUSION}

Dietary patterns change over time and monitoring risk factors for developing metabolic complications post-transplant should be a clinical priority. Post-transplant weight gain, particularly visceral fat gain, increases the risk of developing NODAT, dyslipidemia, and CVD. Higher quality research studies, namely randomized controlled trials, are needed to properly develop guidelines and implement clinical protocols to prevent malnutrition posttransplant.

\section{AUTHOR CONTRIBUTIONS}

JN and LM researched and drafted the contents of this manuscript.

\section{REFERENCES}

1. Kalantar-Zadeh K, Kopple JD, Block G, Humphreys MH. A malnutrition-inflammation score is correlated with morbidity and mortality in maintenance hemodialysis patients. Am J Kidney Dis. (2001) 38:1251-63. doi: 10.1053/ajkd.2001. 29222

2. Pereira RA, Cordeiro AC, Avesani CM, Carrero JJ, Lindholm B, Amparo FC, et al. Sarcopenia in chronic kidney disease on conservative therapy: prevalence and association with mortality. Nephrol Dial Transplant. (2015) 30:1718-25. doi: $10.1093 / \mathrm{ndt} / \mathrm{gfv} 133$

3. Ozkayar N, Altun B, Halil M, Kuyumcu ME, Arik G, Yesil Y, et al. Evaluation of sarcopenia in renal transplant recipients. Nephrourol Mon. (2014) 6:e20055. doi: 10.5812/numonthly.20055

4. Johnson CP, Gallagher-Lepak S, Zhu YR, Porth C, Kelber S, Roza AM, et al. Factors influencing weight gain after renal transplantation. Transplantation (1993) 56:822-7. doi: 10.1097/00007890-199310000-00008

5. Moore L, Gaber AO. Patterns of early weight change after renal transplantation. $J$ Renal Nutr. (1996) 6:21-5. doi: 10.1016/S1051-2276(96)90104-1

6. Clunk JM, Lin CY, Curtis JJ. Variables affecting weight gain in renal transplant recipients. Am J Kidney Dis. (2001) 38:349-53. doi: 10.1053/ajkd.2001.26100 
7. Cashion AK, Sanchez ZV, Cowan PA, Hathaway DK, Lo Costello A, Gaber AO. Changes in weight during the first year after kidney transplantation. Prog Transplant. (2007) 17:40-7. doi: 10.1177/152692480701 700106

8. Todd J, Schmidt M, Christain J, Williams R. The low-bacteria diet for immunocompromised patients. Reasonable prudence or clinical superstition? Cancer Pract. (1999) 7:205-7.

9. Haller MC, van der Veer SN, Nagler EV, Tomson C, Lewington A, Hemmelgarn BR, et al. A survey on the methodological processes and policies of renal guideline groups as a first step to harmonize renal guidelines. Nephrol Dial Transplant. (2015) 30:1066-74. doi: 10.1093/ndt/gfu288

10. KDIGO. KDIGO clinical practice guideline for the care of kidney transplant recipients. Am J Transplant. (2009) 9 (Suppl. 3):S1-155. doi: 10.1111/j.1600-6143.2009.02834.x

11. Fry K, Patwardhan A, Ryan C, Trevillian P, Chadban S, Westgarth $\mathrm{F}$, et al. Development of evidence-based guidelines for the nutritional management of adult kidney transplant recipients. J Ren Nutr. (2009) 19:1014. doi: 10.1053/j.jrn.2008.10.010

12. Ha K, Kim K, Chun OK, Joung H, Song Y. Differential association of dietary carbohydrate intake with metabolic syndrome in the US and Korean adults: data from the 2007-2012 NHANES and KNHANES. Eur J Clin Nutr. (2018) 72:848-60. doi: 10.1038/s41430-017-0031-8

13. 2015-2020 Dietary Guidelines for Americans. 8th ed. (2015). Available online at: https://health.gov/dietaryguidelines/2015/guidelines/ (Accessed June 5, 2018).

14. Mottillo S, Filion KB, Genest G, Joseph L, Pilote L, Poirier P, et al. The metabolic syndrome and cardiovascular risk: a systematic review and metaanalysis. J Am Coll Cardiol. (2010) 56:1113-32. doi: 10.1016/j.jacc.2010.05.034

15. Large V, P A. Pathophysiological modulation in obesity, diabetes, and hyperlipidaemia. Diabetes Metabol. (1998) 24:409-18.

16. Wissing KM, Pipeleers L. Obesity, metabolic syndrome and diabetes mellitus after renal transplantation: prevention and treatment. Transplant Rev (Orlando) (2014) 28:37-46. doi: 10.1016/j.trre.2013.12.004

17. Altunkaynak ME, Özbek E, Altunkaynak BZ, Can I, Unal D, Unal B. The effects of high-fat diet on the renal structure and morphometric parametric of kidneys in rats. J Anat. (2008) 212:845-52. doi: 10.1111/j.1469-7580.2008.00902.x

18. Arici M, Brown J, Williams M, Harris KP, Walls J, Brunskill NJ. Fatty acids carried on albumin modulate proximal tubular cell fibronectin production: a role for protein kinase C. Nephrol Dial Transplant. (2002) 17:1751-7. doi: $10.1093 / \mathrm{ndt} / 17.10 .1751$

19. Klooster A, Hofker HS, Navis G, Homan van der Heide JJ, Gans RO, van Goor $\mathrm{H}$, et al. Nonesterified fatty acids and development of graft failure in renal transplant recipients. Transplantation (2013) 95:1383-9. doi: 10.1097/TP.0b013e31828b8f9b

20. Sieber J, Lindenmeyer MT, Kampe K, Campbell KN, Cohen CD, Hopfer $\mathrm{H}$, et al. Regulation of podocyte survival and endoplasmic reticulum stress by fatty acids. Am J Physiol Renal Physiol. (2010) 299:F821-9. doi: 10.1152/ajprenal.00196.2010

21. Soumura M, Kume S, Isshiki K, Takeda N, Araki S, Tanaka Y, et al. Oleate and eicosapentaenoic acid attenuate palmitate-induced inflammation and apoptosis in renal proximal tubular cell. Biochem Biophys Res Commun. (2010) 402:265-71. doi: 10.1016/j.bbrc.2010.10.012

22. Lim AK, Manley KJ, Roberts MA, Fraenkel MB. Fish oil for kidney transplant recipients. Cochrane Database Syst Rev. (2016) CD005282. doi: 10.1002/14651858.CD005282.pub3

23. Pranger IG, Gruppen EG, van den Berg E, Soedamah-Muthu SS, Navis G, Gans RO, et al. Intake of n-3 fatty acids and long-term outcome in renal transplant recipients: a post hoc analysis of a prospective cohort study. $\mathrm{Br} J$ Nutr. (2016) 116:2066-73. doi: 10.1017/s0007114516004207

24. de Alaniz MJ, Marra CA. Steroid hormones and fatty acid desaturases. Prostaglandins Leukot Essent Fatty Acids (2003) 68:163-70. doi: 10.1016/S0952-3278(02)00266-1

25. Nakamura MT, Nara TY. Structure, function, and dietary regulation of delta6, delta5, and delta9 desaturases. Annu Rev Nutr. (2004) 24:345-76. doi: 10.1146/annurev.nutr.24.121803.063211

26. Palmer SC, Maggo JK, Campbell KL, Craig JC, Johnson DW, Sutanto B, et al. Dietary interventions for adults with chronic kidney disease. Cochrane Database Syst Rev. (2017) 4:Cd011998. doi: 10.1002/14651858.CD011998.pub2

27. Goral S, Bleicher MB. Handbook of Nutrition and the Kidney. Philadelphia, PA: Lippincott Williams and Wilkins (2010).

28. Chadban S, Chan M, Fry K, Patwardhan A, Ryan C, Trevillian P, et al. The CARI guidelines. Protein requirement in adult kidney transplant recipients. Nephrology (Carlton) (2010) 15 (Suppl. 1):S68-71. doi: 10.1111/j.1440-1797.2010.01238.x

29. Werzowa JM, Saemann MD, Mohl A, Bergmann M, Kaltenecker CC, Brozek W, et al. A randomized controlled trial-based algorithm for insulin-pump therapy in hyperglycemic patients early after kidney transplantation. PLoS ONE (2018) 13:e0193569. doi: 10.1371/journal.pone. 0193569

30. van Wijngaarden RPT, Overbeek JA, Heintjes EM, Schubert A, Diels J, Straatman $\mathrm{H}$, et al. Relation between different measures of glycemic exposure and microvascular and macrovascular complications in patients with type 2 diabetes mellitus: an observational cohort study. Diabetes Therapy (2017) 8:1097-109. doi: 10.1007/s13300-017-0301-4

31. Boloori A, Saghafian S, Chakkera HA, Cook CB. Characterization of remitting and relapsing hyperglycemia in post-renal-transplant recipients. PLoS ONE (2015) 10:e0142363. doi: 10.1371/journal.pone.0142363

32. Luan FL, Steffick DE, Ojo AO. New-onset diabetes mellitus in kidney transplant recipients discharged on steroid-free immunosuppression. Transplantation (2011) 91:334-41. doi: 10.1097/TP.0b013e318203c25f

33. Pirsch JD, Henning AK, First MR, Fitzsimmons W, Gaber AO, Reisfield R, et al. New-onset diabetes after transplantation: results from a double-blind early corticosteroid withdrawal trial. Am J Transplant. (2015) 15:1982-90. doi: 10.1111/ajt.13247

34. Woodle ES, First MR, Pirsch J, Shihab F, Gaber AO, Van Veldhuisen P. A prospective, randomized, double-blind, placebo-controlled multicenter trial comparing early (7 day) corticosteroid cessation versus longterm, low-dose corticosteroid therapy. Ann Surg. (2008) 248:564-77. doi: 10.1097/SLA.0b013e318187d1da

35. Hasse JM. Nutrition assessment and support of organ transplant recipients. JPEN J Parenter Enteral Nutr. (2001) 25:120-31. doi: $10.1177 / 0148607101025003120$

36. McKane CK, Marmarelis M, Mendu ML, Moromizato T, Gibbons FK, Christopher KB. Diabetes mellitus and community-acquired bloodstream infections in the critically ill. J Crit Care (2014) 29:70-6. doi: 10.1016/j.jcrc.2013.08.019

37. Terranova A. The effects of diabetes mellitus on wound healing. Plast Surg Nurs. (1991) 11:20-5. doi: 10.1097/00006527-199121000-00006

38. Vincent AM, Russell JW, Low P, Feldman EL. Oxidative stress in the pathogenesis of diabetic neuropathy. Endocr Rev. (2004) 25:612-28. doi: 10.1210/er.2003-0019

39. Huber L, Naik M, Budde K. Frequency and long-term outcomes of posttransplant hypophosphatemia after kidney transplantation. Transpl Int. (2013) 26:e94-96. doi: 10.1111/tri.12145

40. Baia LC, Heilberg IP, Navis G, de Borst MH. Phosphate and FGF-23 homeostasis after kidney transplantation. Nat Rev Nephrol. (2015) 11:656-66. doi: 10.1038/nrneph.2015.153

41. van Londen M, Aarts BM, Deetman PE, van der Weijden J, Eisenga MF, Navis G, et al. Post-transplant hypophosphatemia and the risk of death-censored graft failure and mortality after kidney transplantation. Clin J Am Soc Nephrol. (2017) 12:1301-10. doi: 10.2215/cjn.10270916

42. Merhi B, Shireman T, Carpenter MA, Kusek JW, Jacques P, Pfeffer M, et al. Serum phosphorus and risk of cardiovascular disease, all-cause mortality, or graft failure in kidney transplant recipients: an ancillary study of the FAVORIT trial cohort. Am J Kidney Dis. (2017) 70:377-85. doi: 10.1053/j.ajkd.2017.04.014

43. Stevens KK, Morgan IR, Patel RK, Geddes CC, Mark PB, Jardine AG, et al. Serum phosphate and outcome at one year after deceased donor renal transplantation. Clin Transplant. (2011) 25:E199-204. doi: 10.1111/j.1399-0012.2011.01400.x

44. Jeon HJ, Kim YC, Park S, Kim CT, Ha J, Han DJ, et al. Association of serum phosphorus concentration with mortality and graft failure among kidney transplant recipients. Clin J Am Soc Nephrol. (2017) 12:653-62. doi: $10.2215 /$ cjn. 07090716 
45. Marcen R, Jimenez S, Fernandez A, Galeano C, Villafruela JJ, Burgos FJ, et al. The effects of mineral metabolism markers on renal transplant outcomes. Transplant Proc. (2012) 44:2567-9. doi: 10.1016/j.transproceed.2012.09.041

46. Nijenhuis T, Hoenderop JG, Bindels RJ. Downregulation of $\mathrm{Ca}^{2+}$ and $\mathrm{Mg}^{2+}$ transport proteins in the kidney explains tacrolimus (FK506)-induced hypercalciuria and hypomagnesemia. J Am Soc Nephrol. (2004) 15:549-57. doi: 10.1097/01.ASN.0000113318.56023.B6

47. Ledeganck KJ, De Winter BY, Van den Driessche A, Jurgens A, Bosmans JL, Couttenye MM, et al. Magnesium loss in cyclosporine-treated patients is related to renal epidermal growth factor downregulation. Nephrol Dial Transplant. (2014) 29:1097-102. doi: 10.1093/ndt/gft498

48. Kao WH, Folsom AR, Nieto FJ, Mo JP, Watson RL, Brancati FL. Serum and dietary magnesium and the risk for type 2 diabetes mellitus: the atherosclerosis risk in communities study. Arch Intern Med. (1999) 159:21519. doi: 10.1001/archinte.159.18.2151

49. Larsson SC, Wolk A. Magnesium intake and risk of type 2 diabetes: a meta-analysis. J Intern Med. (2007) 262:208-14. doi: 10.1111/j.1365-2796.2007.01840.x

50. Dong JY, Xun P, He K, Qin LQ. Magnesium intake and risk of type 2 diabetes: meta-analysis of prospective cohort studies. Diabetes Care (2011) 34:2116-22. doi: $10.2337 / \mathrm{dc} 11-0518$

51. Xu T, Chen GC, Zhai L, Ke KF. Nonlinear reduction in risk for type 2 diabetes by magnesium intake: an updated meta-analysis of prospective cohort studies. Biomed Environ Sci. (2015) 28:527-34. doi: 10.3967/bes2015.075

52. Fang X, Wang K, Han D, He X, Wei J, Zhao L, et al. Dietary magnesium intake and the risk of cardiovascular disease, type 2 diabetes, and all-cause mortality: a dose-response meta-analysis of prospective cohort studies. BMC Med. (2016) 14:210. doi: 10.1186/s12916-016-0742-z

53. Van Laecke S, Nagler EV, Taes Y, Van Biesen W, Peeters P, Vanholder R. The effect of magnesium supplements on early post-transplantation glucose metabolism: a randomized controlled trial. Transplant Int. (2014) 27:895-902. doi: $10.1111 /$ tri. 12287

54. de Lordes Lima M, Cruz T, Pousada JC, Rodrigues LE, Barbosa K, Cangucu V. The effect of magnesium supplementation in increasing doses on the control of type 2 diabetes. Diabetes Care (1998) 21:682-6. doi: $10.2337 /$ diacare.21.5.682

55. Santos L, Rodrigo E, Pinera C, Robledo C, Palomar R, Gomez-Alamillo C, et al. Elevated serum gamma-glutamyltransferase and hypomagnesemia are not related with new-onset diabetes after transplantation. Transplant Proc. (2010) 42:2914-6. doi: 10.1016/j.transproceed.2010.07.057

56. Van Laecke S, Caluwe R, Huybrechts I, Nagler EV, Vanholder R, Peeters $\mathrm{P}$, et al. Effect of magnesium supplements on insulin secretion after kidney transplantation: a randomized controlled trial. Ann Transplant. (2017) 22:524-31. doi: 10.12659/AOT.903439

57. Querings K, Girndt M, Geisel J, Georg T, Tilgen W, Reichrath J. 25hydroxyvitamin D deficiency in renal transplant recipients. J Clin Endocrinol Metab. (2006) 91:526-9. doi: 10.1210/jc.2005-0547

58. Rizvi SM, Veierod MB, Thorsby PM, Helsing P. Vitamin D in Norwegian renal transplant recipients: a longitudinal study with repeated measurements in winter and summer. Eur J Dermatol. (2015) 25:234-9. doi: 10.1684/ejd.2015.2524

59. Vangala C, Pan J, Cotton RT, Ramanathan V. Mineral and bone disorders after kidney transplantation. Front Med. (2018) 5:211. doi: 10.3389/fmed.2018.00211

60. Edwards MS, Doster S. Renal transplant diet recommendations: results of a survey of renal dietitians in the United States. J Am Diet Assoc. (1990) 90:843-6.
61. Woodward RS, Schnitzler MA, Baty J, Lowell JA, Lopez-Rocafort L, Haider S, et al. Incidence and cost of new onset diabetes mellitus among U.S. wait-listed and transplanted renal allograft recipients. Am J Transplant. (2008) 3:590-8. doi: 10.1034/j.1600-6143.2003.00082.x

62. Workeneh BT, Moore LW, Nolte Fong JV, Osama AG, Mitch WE. Adverse metabolic responses following kidney transplantation stimulate the production of visceral adipose tissue. In: 19th International Congress on Nutrition and Metabolism in Renal Disease. Genova (2018).

63. Cupples CK, Cashion AK, Cowan PA, Tutor RS, Wicks MN, Williams R, et al. Characterizing dietary intake and physical activity affecting weight gain in kidney transplant recipients. Prog Transplant. (2012) 22:62-70. doi: $10.7182 /$ pit2012888

64. Oste MCJ, Gomes-Neto AW, Corpeleijn E, Gans ROB, de Borst MH, van den Berg E, et al. Dietary Approach to Stop Hypertension (DASH) diet and risk of renal function decline and all-cause mortality in renal transplant recipients. Am J Transplant. (2018) 18:2523-33. doi: 10.1111/ajt. 14707

65. Sharif A, Moore R, Baboolal K. Influence of lifestyle modification in renal transplant recipients with postprandial hyperglycemia. Transplantation (2008) 85:353-8. doi: 10.1097/TP.0b013e31816 $05 \mathrm{ebf}$

66. Wilcox J, Waite C, Tomlinson L, Driscoll J, Karim A, Day E, et al. Comparing glycaemic benefits of Active Versus passive lifestyle Intervention in kidney Allograft Recipients (CAVIAR): study protocol for a randomised controlled trial. Trials (2016) 17:417. doi: 10.1186/s13063-0161543-6

67. Ryan KJ, Casas JM, Mash LE, McLellan SL, Lloyd LE, Stinear JW, et al. The effect of intensive nutrition interventions on weight gain after kidney transplantation: protocol of a randomised controlled trial. BMC Nephrol. (2014) 15:148. doi: 10.1186/1471-2369-15-148

68. Klaassen G, Zelle DM, Navis GJ, Dijkema D, Bemelman FJ, Bakker SJL, et al. Lifestyle intervention to improve quality of life and prevent weight gain after renal transplantation: design of the Active Care after Transplantation (ACT) randomized controlled trial. BMC Nephrol. (2017) 18:296. doi: 10.1186/s12882-017-0709-0

69. Lawrence IR, Thomson A, Hartley GH, Wilkinson R, Day J, Goodship THJ. The effect of dietary intervention on the management of hyperlipidemia in British renal transplant patients. J Renal Nutr. (1995) 52:73-7. doi: 10.1016/1051-2276(95)90096-9

70. Patel MG. The effect of dietary intervention on weight gains after renal transplantation. $J$ Ren Nutr. (1998) 8:137-41. doi: 10.1016/S1051-2276(98)90005-X

71. Guida B, Trio R, Laccetti R, Nastasi A, Salvi E, Perrino NR, et al. Role of dietary intervention on metabolic abnormalities and nutritional status after renal transplantation. Nephrol Dial Transplant. (2007) 22:3304-10. doi: $10.1093 / \mathrm{ndt} / \mathrm{gfm} 345$

Conflict of Interest Statement: The authors declare that the research was conducted in the absence of any commercial or financial relationships that could be construed as a potential conflict of interest.

Copyright (C) 2018 Nolte Fong and Moore. This is an open-access article distributed under the terms of the Creative Commons Attribution License (CC BY). The use, distribution or reproduction in other forums is permitted, provided the original author(s) and the copyright owner(s) are credited and that the original publication in this journal is cited, in accordance with accepted academic practice. No use, distribution or reproduction is permitted which does not comply with these terms. 